Respiration 2010;79:437-438

DOI: $\underline{10.1159 / 000277664}$

\section{Serum Chitotriosidase Levels in Patients with Allergic and Non-Allergic Asthma}

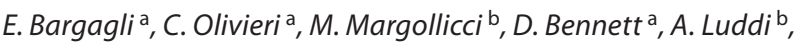 \\ M. Perrone a , C. Maggiorelli a , A. Prasse ${ }^{c}$, P. Rottoli ${ }^{a}$ \\ a Sezione di Malattie Respiratorie, Dipartimento di Medicina \\ Clinica e Scienze Immunologiche, and 'bSezione di Pediatria, \\ Università degli Studi di Siena, Siena, Italy; ${ }^{\mathrm{C}}$ Department of \\ Pneumology, Freiburg University, Freiburg, Germany
}

Asthma is a complex inflammatory disorder of the airways characterized by bronchial hyper-reactivity to different stimuli, and its pathogenesis is not always completely clear. Chitinases and chitinase-like proteins have recently been proposed as molecules involved in the pathogenesis of asthma with a possible role as prognostic biomarkers [1-6].

Higher serum concentrations of YKL-40 (chitinase-3-like-1), a 'mammalian chitinase-like protein', have been reported $[2,4,5]$ in asthma patients and hyper-responsive subjects than in controls. The YKL-40 gene has been associated with genetic susceptibility to the disease. Acid mammalian chitinase (AMCase) has been studied in animal models of airway inflammation [3] and AMCase gene expression has been investigated in detail in BAL fluid macrophages and epithelial brushing from asthma patients $[1,5]$.

Another member of the chitinase 1 family not yet studied in detail in asthma is chitotriosidase, an enzyme produced by activated macrophages, structurally similar to YKL-40 but having chitinolytic activity $[7,8]$. In the last 5 years our research group has investigated the role of chitotriosidase in the pathogenesis of different inflammatory lung diseases, such as sarcoidosis [9]. Here we analyzed serum concentrations of chitotriosidase in allergic and non-allergic asthma patients and in a group of controls to evaluate its potential involvement in the different pathways of inflammation occurring in this disease.

Chitotriosidase concentrations were measured in serum samples from 23 patients with allergic asthma, 19 non-allergic asthmatics and 35 healthy controls by a fluorimetric method (Sigma, St. Louis, Mo., USA). Selected patients with PC20 methacholine less than $8 \mathrm{mg} / \mathrm{ml}$ were followed at our centre for almost 5 years. They were divided into allergic and non-allergic groups according to medical history, prick test and RAST test results. All patients performed lung function tests, chest X-ray and total IgE analysis at the time of serum sampling. Statistical analysis was performed using Windows software (2005) Graph Pad Prism version 4.0.

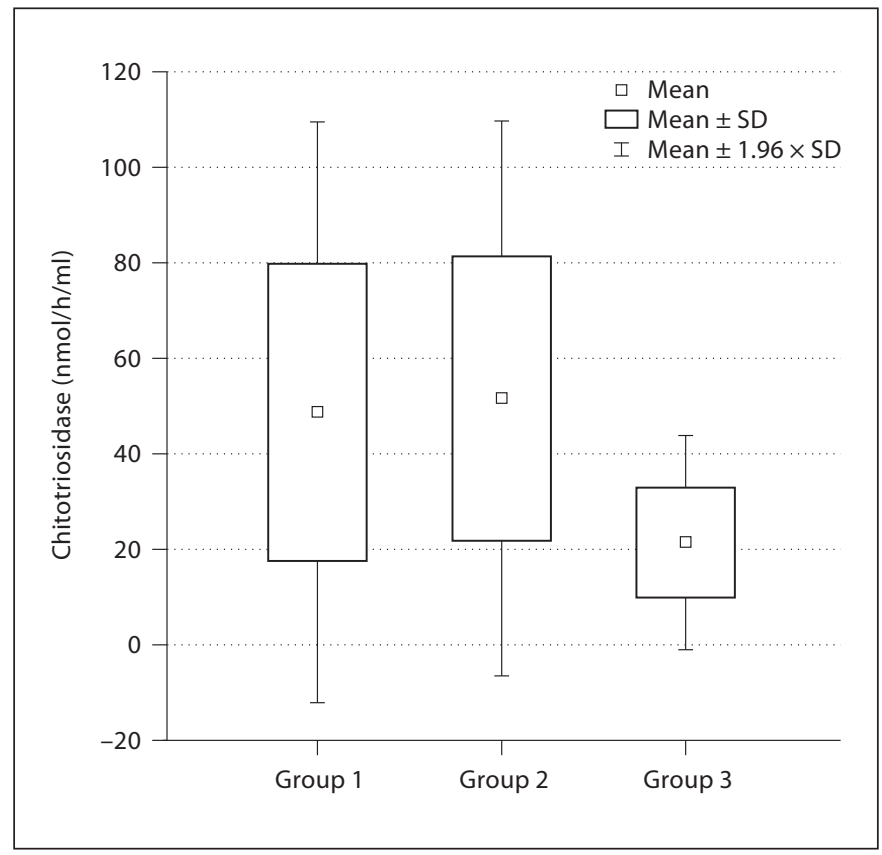

Fig. 1. Chitotriosidase concentrations in patients with allergic asthma (group 1), non-allergic asthma (group 2) and in controls (group 3).

Since the data did not have a normal distribution (Shapiro-Wilk's test), statistical differences were detected by the Kruskal-Wallis test $(\mathrm{p}<0.05)$.

Serum concentrations of chitotriosidase were $48.72 \pm 31$ $\mathrm{nmol} / \mathrm{h} / \mathrm{ml}$ in allergic asthmatics, $51.5 \pm 29 \mathrm{nmol} / \mathrm{h} / \mathrm{ml}$ in nonallergic asmathics and $21.42 \pm 11 \mathrm{nmol} / \mathrm{h} / \mathrm{ml}$ in controls (fig. 1). Significant differences were found between the concentrations of chitotriosidase in asthmatics and controls $(p<0.05)$. Concentrations of chitotriosidase greater than normal values were observed in $60 \%$ of allergic and $63 \%$ of non-allergic asthmatics. No significant differences were found between chitotriosidase concentrations in allergic and non-allergic patients, although the highest concentrations of chitotriosidase were found in 4 patients with documented allergy to dust and moulds.

Tercelj et al. [8] studied serum chitotriosidase activity in various lung diseases, finding concentrations of chitotriosidase in a small population of asthmatics similar to ours. Unfortunately this study did not divide patients according to their history of allergy or specify whether any groups of patients had higher chitotriosidase concentrations.

\section{KARGER}

Fax +41613061234 E-Mail karger@karger.ch www.karger.com
(C) 2010 S. Karger AG, Base

0025-7931/10/0795-0437\$26.00/0

www.karger.com/res 
In conclusion, though preliminary, this data suggests that chitotriosidase is much more enhanced in serum of asthma patients than controls. Further studies focusing on specific subgroups of patients (e.g. subjects allergic to mites and mould) in whom enzyme concentrations are very high could also be performed to investigate whether chitinolytic activity is mainly enhanced in specific categories of allergies.

\section{References}

1 Seibold MA, Donnelly S, Solon M, et al: Chitotriosidase is the primary active chitinase in the human lung and is modulated by genotype and smoking habit. J Allergy Clin Immunol 2008;122:944-950.

-2 Ober C, Tan Z, Sun Y, et al: Effect of variation in CHI3L1 on serum YKL-40 level, risk of asthma, and lung function. N Engl J Med 2008; 358:1682-1691.

- 3 Zhu Z, Zheng T, Homer RJ, Kim YK, Chen NY, Cohn L, et al: Acid mammalian chitinase in asthmatic Th2 inflammation and IL-13 pathway activation. Science 2004;304:1678-1691.

-4 Chupp G, Lee CG, Jarjour N, et al: A chitinase-like protein in the lung and circulation of patients with severe asthma. New Engl J Med 2007; 357:2016-2027.
5 Shuhui L, Mok YK, Wong WSF: Role of mammalian chitinases in asthma. Int Arch Allergy Immunol 2009;149:369-377.

6 Lee CG: Chitin, chitinases and chitinase-like proteins in allergic inflammation and tissue remodelling. Yonsei Med J 2009;50:22-30.

7 Barone R, Sotgiu S, Musumeci S: Plasma chitotriosidase in health and pathology. Clin Lab 2007;53:321-333.

8 Tercelj M, Salobir B, Simcic S, Wraber B, Zupancic M, Rylander R: Chitotriosidase activity in sarcoidosis and some other pulmonary diseases. Scand J Clin Lab Invest 2009;1-4.

9 Bargagli E, Margollicci M, Nikiforakis N, et al: Chitotriosidase activity in the serum of patients with sarcoidosis and pulmonary tuberculosis. Respiration 2007;74:548-552.

Elena Bargagli, MD, $\mathrm{PhD}$

Sezione di Malattie Respiratorie, Policlinico Le Scotte Viale Bracci

IT-53100 Siena (Italy)

Tel. +39057 758 6710, Fax +39057 7280744

E-Mail bargagli2@gmail.com 